\title{
PEMBINAAN PENGELOLAAN MANAJEMEN USAHA DAN E-MARKETING PADA PELAKU USAHA INDUSTRI MIKRO PENGRAJIN SEPATU DI KECAMATAN MEDAN DENAI
}

\author{
Muhammad Irfan Nasution ${ }^{1 *}$, Muhammad Andi Prayogi ${ }^{1}$, \\ Satria Mirsya Affandy Nasution ${ }^{1}$ \\ Program Studi manajemen Fakultas Ekonomi dan Bisnis Universitas Muhammadiyah Sumatera Utara \\ Jl. Kapt. Mukhtar Basri No. 3 Medan Sumatera Utara 20238 Indonesia \\ * Penulis Korespodensi: muh_f4n@yahoo.co.id
}

\begin{abstract}
Abstrak
Kegiatan program pengabdian masyarakat dari Lembaga Pengabdian Pada Masyarakat (LPPM) Universitas Muhammadiyah Sumatera Utara ini bertujuan untuk melakukan Pembinaan Pengelolaan Manajemen Usaha dan E-Marketing pada Pelaku Usaha Industri Mikro Pengrajin Sepatu di Kecamatan Medan Denai. Kegiatan pengabdian masyarakat ini melibatkan pengrajin Sepatu yang akan menjadi Mitra pengabdian masyarakat yaitu Jondy Shoes dan Whindy Shoes. Pengabdian masyarakat ini dilaksanakan selama 8 (delapan) bulan dengan target luaran utama adalah publikasi jurnal ilmiah pengabdian masyarakat, memperoleh ijin usaha, mempunyai website dann peningkatan wawasan dan keterampilan. Metode yang digunakan dalam kegiatan pengabdian masyarakat ini adalah pendekatan partisipatif, pendekatan kognitif, pendekatan afektif dan pendekatan keterampilan dan tahapan tahapan yang digunakan adalah persiapan, investigasi, transformasi. Incubation, verification, implementation, evaluasi, pengembangan secara bertahap yang dimulai dengan Plan, do, action, check. Selanjutnya para mitra sudah mempunyai email dan webblog sebagai sarana promosi usaha yang mitra jalankan dan sudah memiliki izin usaha dan telah terdaftar di Dinas Koperasi Kota medan.
\end{abstract}

Kata Kunci: manajemen usaha, e-marketing

\begin{abstract}
The activities of the public service program of the community service Society or LP2M Univesity of Muhammadiyah Sumatera Utara aims to perform the construction Management Business Management and E-Marketing in Micro Industry Trade Craftsmen shoes in Medan Denai. This outreach activities involving craftsmen shoes that will become a partner of public service i.e. Jondy Whindy Shoes and Shoes. Public service was conducted for 8 (eight) months with the outer primary target was the publication of the scientific journal public service, obtaining a business license, have increased insight and dann website skills. Methods used in this outreach activity is a participatory approach, the approach of cognitive, affective and approach the approach phase and stage skills used are preparation, investigation, transformation. Incubation, verification, implementation, evaluation, development gradually, beginning with a Plan, do, check, action. Furthermore the partners already have email and webblog as a means of promotion of the business partners who run and already have a business license and has been registered with the Department of Cooperatives of medan
\end{abstract}

Keywords: Business Management, E-Marketing

\section{PENDAHULUAN}

Kecamatan Medan Denai merupakan Kecamatan di Kota Medan yang mempunyai luas wilayah sekitar 9,91 km2 dengan ketinggian wilayah 25 meter di atas permukaan laut. Secara geografis, di sebelah Utara Kecamatan Medan Denaiberbatasan langsung dengan Kecamatan Medan Tembung, sebelah selatan berbatasan dengan Kecamatan Medan Amplas,sebelah Barat berbatasan dengan Kecamatan Medan Area, sedangkan di sebelah Timur berbatasan dengan Kabupaten Deli Serdang Kelurahan Binjai merupakan kelurahan terluas di Kecamatan Medan Denai yaitu sekitar 4,14km2 atau sebesar 41,77 persen dari total luas Kecamatan Medan Denai, sedangkan 
kelurahan dengan wilayah terkecil yaitu Kelurahan Tegal Sari Mandala I dengan luas wilayah hanya 0,50 $\mathrm{km} 2$ atau sebesar 5,05 persen dari luas wilayah Kecamatan Medan Denai secara total. (Badan Pusat Statistik, 2016).

Keberadaan usaha mikro di Kecamatan Medan Denai merupakan daerah pengembangan industri mikro, kegiatan usaha mikro yang dilakukan di Kecamatan Medan Denai secara bertahap telah banyak berkembang dan menghasilkan produk unggulan salah satunya adalah pengrajin sepatu, sebagian usaha tersebut berpotensi untuk dikembangkan, baik kualitas dan kuantitas produk maupun pengembangan pasar, bila di dorong untuk berkolaborasi dan kerjasama ditingkat yang lebih luas, pelaku usaha akan sangat produktif bila sejalan dan sinergis dengan kebijakan dan program Pemerintah Kota/Kabupaten maupun lembaga-lembaga terkait dalam mengembangkan produk unggulan para pelaku usaha pengrajin sepatu di Kecamatan Medan Denai.

Usaha kecil pengrajin sepatu saat ini masih menghadapi permasalahan yang cukup banyak dan beragam. Permasalahan utama yang dihadapi adalah mengenai manajemen usaha baik manajemen produksi, permasalah ini diperkuat dengan hasil penelitian Ay Ling (2013) yang menyatakan bahwa proses produksi merupakan tahapan yang sangat penting bagi perusahaan, dimana pada tahap ini barang mentah diolah menjadi barang jadi yang nantinya akan dijual kepada konsumen untuk pemuasan kebutuhan dan pengelolaan keuangan, modal dan pembiyaan usaha, pengembangan teknologi, pemasaran, sumber daya manusia, birokrasi dan kemitraan.

Sementara itu kelemahan mendasar yang dihadapi pengrajin sepatu dalam bidang pemasaran adalah orientasi pasar rendah, lemah dalam persaingan yang kompleks dan tajam serta tidak memadainya infrastruktur pemasaran. Menghadapi mekanisme pasar yang makin terbuka dan kompetitif, penguasaan pasar merupakan prasyarat untuk meningkatkan daya saing. Oleh karena itu, peran pemerintah maupun kemitraan swasta diperlukan dalam mendorong keberhasilan pengrajin sepatu untuk memperluas akses pasar melalui pemberian fasilitas teknologi informasi berbasis web yang dapat digunakan sebagai media komunikasi bisnis global. Teknologi Internet dapat digunakan sebagai media pemasaran yang efektif, dengan jangkauan yang sangat luas tidak terbatas oleh ruang dan waktu. Oleh karena itu para pelaku usaha kecil dan menengah harus memanfaatkannya sebagai sarana untuk meningkatkan jangkauan pasar, baik tingkat nasional maupun internasional (Djamaludin, dkk, 2016). Djamaludin, dkk (2016) lebih lanjut menjelaskan bahwa Strategi bisnis dalam pemasaran dan promosi produk UKM Dengan media sosial internet merupakan salah satu hal yang perlu di lakukan dalam upaya memperluas jejaring pasar baik di tingkat lokal, nasional maupun internasional.dan Dengan memahami strategi Bisnis dalam pemasaran dan promosi produk UKM Dengan media sosial di internet, strategi online marketing membuat usaha seakan akan 24 jam non stop dan dapat di akses seluruh dunia dan tidak banyak mengeluarkan banyak biaya. Sedangkan menurut Nuryanti (2013:5), di era globalisasi informasi bergerak sangat cepat dan menjadi pelaku bisnis untuk memenangkan persaingan. Internet melalui $e$ commerce membuka peluang bagi usaha kecil dan menengah (UKM) untuk memasarkan dan menumbuhkan jaringan usaha di seluruh belahan dunia usaha. Untuk itu pelaku Usaha Kecil dan Menengah (UKM) dituntut menjadi bagian dari komonitas global dengan pemanfaatan teknologi informasi melalui e-commerce, jika mereka tidak mengikuti perkembangan teknologi informasi akan tertinggal jauh dan kalah dalam persaingan. $E$ commerce merupakan salah satu cara yang dapat dilakukan oleh pelaku usaha Kecil dan Menengah (UKM) untuk memasarkan produknya selain dapat memperluas akses pasar. Usaha Kecil dan Menengah (UKM) harus melihat manfaat e-commerce untuk akses pasar secara mudah dan effisien seiring era globalisasi yang pasti akan dihadapi.

Berdasarkan hasil analisis terhadap beberapa hasil penelitian dan hasil diskusi dengan Mitra pelaku usaha pengrajin sepatu yaitu Jondy Shoes dan Windys Shoes pada saat obervasi yang dilakukan pada bulan Oktober 2016, teridentifikasi beberapa masalah dalam manajemen usaha dan pemasaran yaitu: 1) Keterbatasan pengetahuan mitra dalam pengelolaan manajemen usaha yang prosfesional, seperti pengelolaan keuangan, administrasi, membuat surat penawaran, dll. 2) Keterbatasan pengetahuan dalam pemanfaatan akses dan penguasaan teknologi, khususnya teknologi internet marketing. 3) Kurang inovasi dalam manajemen usaha baik di bidang pemasaran, produksi maupun strategi penjualan, terbatasnya waktu untuk terjun secara total dalam usaha, sehingga mereka tidak punya waktu untuk kegiatan pelatihan usaha, dll, 4) Merek dari produk yang dihasilkan oleh pengrajin tidak terdaftar, hal ini disebabkan karena biaya untuk mendaftarkan merek dari hasil produk sangat mahal. Merek yang mereka buat adalah merk sendiri atau tidak bermerk.

Keempat permasalahan yang telah diuraikan tersebut merupakan permasalahan yang sangat mendesak untuk dicarikan solusinya, sehingga diharapkan setelah selesai kegiatan program pembinaann ipteks bagi masyarakat ini, mitra pelaku usaha yang ada di Kecamatan Medan Denai sudah memiliki kemampuan untuk mengaplikasikan manajemen usaha dan menggunakan internet marketing untuk menjangkau pasar yang lebih luas, kemudia sudah mempunyai merk sendiri sehingga mempunyai nilai jual yang tinggai dan telah mempunyai izin usaha.

Dengan demikian diharapkan UKM dapat mendapatkan berbagai keuntungan dalam mempromosikan usahanya, mengakses informasi faktor-faktor produksi, melakukan transaksi usaha, serta melakukan komunikasi bisnis lainnya secara global, dalam rangka memperluas jaringan usahanya. Hasil penelitian memperlihatkan bahwa pemasaran 
melalui internet berpengaruh positif terhadap pemprosesan informasi. Hal tersebut mengindikasikan bahwa kegiatan promosi atas suatu produk akan lebih optimal hasilnya apabila program periklanan yang dilakukan pada media internet juga diimbangi dengan tingginya pemasaran melalui e-mail, maka pemprosesan informasi oleh konsumen akan semakin baik (Mujiyana, dkk 2012).

\section{Aspek Manajemen Usaha dan Pemasaran Mitra}

Manajemen usaha kecil dikelola dengan cara sederhana oleh keluarga, secara turun temurun dan hanya memenuhi kebutuhan keluarga.Tidak adanya sistem pembukuan yang mengikuti kaidah administrasi pembukuan standar. Tidak menerapkan standar mutu dan hanya berdasarkan pengalaman, cara pemasaran yang dilakukan hanya sebatas konvensional yaitu personal selling (dari mulut ke mulut), hanya berdasarkan pesanan yang ada, tidak menggunakan fasilitas internet. Penggunaan $e$ marketing juga belum diterapkan oleh kedua Mitra tersebut sehingga sangat menyulitkan mitra untuk membangun jaringan kepada pihak luar dan produk yang mereka produksi juga sulit untuk ditemukan atau dikenal consumen.

\section{METODE}

\section{Tahapan Pelaksanaan}

Untuk melaksanakan program pengabdian masyarakat, dalam bidang manajemen usaha dan $e$ marketing, maka dilakukan secara bermitra (berkolaborasi) antara Tim pengabdian masyarakat dari dosen-dosen Universitas Muhammadiyah Sumatera Utara dengan Pengrajin Sepatu Jondy (pengrajin sepatu laki-laki) sebagai Mitra 1 (satu) dan Pengrajin Sepatu Whindy (pengrajin sepatu perempuan) sebagai Mitra 2 (dua). Peran Mitra 1 dan Mitra 2, adalah memberikan data-data tentang permasalahan ril yang dihadapi dalam menjalan usaha, kemudian berkoordinasi dengan Tim Pengabdian Masyarakat untuk menentukan langkah-langka apa yang layak dan memenuhi syarat untuk diikut sertakan dalam program pengabdian masyarakat dari LPPM Universitas Muhammadiyah Sumatera Utara. Agar pelaksanaan pengabdian masyarakat ini lebih terarah, maka tahapan atau langkah-langkah yang akan digunakan adalah: (1) Persiapan. Suatu Kondisi yang memberi kemudahan kepada Mitra untuk memunculkan kreativitasnya (Suherman, 2012:77). Ini diperoleh dengan Workshop, mendengar keluhan mitra, menampung ide-ide kratif mitra. (2) Investigasi. Dalam hal ini ada kegiatan yang harus dilakukan yaitu mempelajari masalah terkait dan mengindentifikasi komponen usaha permasalahan (Suherman, 2012:77). Melakukan wawancara kepada Mitra 1 dan Mitra 2, Observasi lapangan. (3) Transformasi. Coba identifikasi persamaan dan perbedaan yang ada serta konfirmasikan dengan data dan informasi yang telah dikumpulkan (Suherman: 2012:77). Menganalisis Jurnal-junal penelitian, informasi dari instansi terkait, yang ada kaitannya dengan program pengabdian masyarakat. (4) Incubation. Masa inkubasi terjadi seakan-akan seseorang keluar atau melupakan masa lalu yang dihadapi "Walk a Way from situation". Kegiatan ini untuk menciptakan suasana rileks dan santai terhadap mitra, sehingga mitra bisa menjauhi masalah dan melupakan masa lalu, dengan harapan mitra bisa berpikir kreatif dalam suasana yang rileks dalam pelaksanaan pengabdian masyarakat. (5) Verification. Untuk memvalidasi ide yang tepat atau akurat, apakah berguna atau tidak, maka dilakukan percobaan (Suherman, 2012:78). Membuat simulasi, test market untuk produk, buat pilot project. (6) Implementation. Mulai mentransformasi ide menjadi kenyataan dan digunakan (Suherman, 2012:78). Disini mitra mulai mengimplementasikan dan membidik target pasar mana yang akan dituju. (7) Evaluasi. Langkah ini merupakan kegiatan untuk mengetahui "nilai lebih" dari hasil kreativitas yang dilakukan (Suherman, 2012:78). Mengevaluasi dari hasil impelementasi yang dilakukan oleh Mitra, apakah masih ada yang perlu diperbaiki dan bagamaimana caranya? (8) Pengembangan. Semua pertanyaan yang dikemukakan pada langkah evaluasi merupakan bahan untuk pengembangan (Suherman, 2012).

\section{Metode Pendekatan}

Metode pendekatan yang ditawarkan untuk menyelesaikan persoalan mitra yang telah disepakati bersama adalah: (1) Metode Pendekatan Partisipatif. Metode Partisipatif adalah Pembelajaran yang berhubugan dengan pengalaman. Metode ini mengawali suatu proses pencerminan, pengujian dan analisis sehingga memiliki potensi membawa seseorang individu ke dalam tahap-tahap pembelajaran yang berhubungan dengan pengalaman (Dwivedi, 2004: 2). Membawa Mitra bertemu dengan orangorang sukses dan berpengalaman dalam mengelola usaha dan langsung berkunjung ke Pelaku usaha yang sukes, agar mitra lebi tertarik dan termotivasi untuk terus mengembangkan usaha dan mengikuti dengan baik program pengabdian masyarakat. (2) Metode Pendekatan Kognitif. Cara yang paling efektif untuk memperkenalkan informasi atau konsep-konsep yang baru pada sekelompok orang yang belajar (Dwivedi, 2004:11). Dalam Pendekatan ini Tim pengabdian masyarakat, mempresentasikan konsep dan informasi dalam suatu cara yang berurutan dan sistematis dalam waktu yang terbatas, menggunakan alat bantu, berdiskusi dengan mitra. (3) Metode Pendekatan Afektif. Partisipasi berbagi pengalaman dan kendali gabungan atas proses pembelajaran (Dwivedi, 2004:25). Memberikan kepada Mitra untuk saling berbagi pengalaman, gagasan, ide, dan mengklarifikasi sudut pandang mitra yang berbeda. Membantu Mitra mengenali apa yang mereka lakukan dan apa yang mitra tidak ketahui, Membantu mitra menjawab pertanyaan-pertanyaan yang mereka hadapi melalui pengalaman, meningkatkan keterlibatan mitra dalam menajalankan usahanya. (4) Metode Pendekatan Keterampilan. Metode berbasis keterampilan ini melibatkan pembelajaran dengan melakukan pembelajaran melalui pengamatan 
(Dwivedi, 2004:103). Mempraktekkan laporan keuangan, sistem administrasi, pembuatan web, blog, media social, dan lain-lain.

\section{Solusi Yang Ditawarkan.}

Alhempi dan Wismar, (2013:20-38) menjelaskan bahwa Pembinaan adalah suatu proses atau pengembangan yang mencakup urutan-urutan pengertian, diawali dengan mendirikan, menumbuhkan, memelihara pertumbuhan tersebut yang disertai usaha usaha perbaikan, menyempurnakan, dan mengembangkannya. Berdasarkan analisis terhadap akar penyebab suatu masalah seperti yang telah diuraikan di atas, maka solusi yang ditawarkan untuk mengatasi permasalahan tentang pembinaan manajemen usaha dan emarketing melalui Pembinaan manajaemen usaha dan e-marketing yang dilakukan sebagai model yang tepat untuk mengatasi permasalah tersebut adalah : (1)

Pembinaan Manajemen Usaha, dalam pembinaan manajemen perlu dilakukan peningkatan SDM, administrasi, dan tekhnologi. (2) Pembinaan SDM, rendahnya tingkat pendidikan, lemahnya keahlian dan manajemen, keahlian pemasaran mencakup aspek produk, biaya distribusi dan promosi. (3) Melakukan Pembinaan mengenai promosi produk kedua mitra baik. (4) Melakukan motivasi pada karyawan agar dapat meningkatkan kreativitasnya sehingga dapat menghasilkan produk yang berkualitas dan diterima oleh pasar. (5) Penguasaan Teknologi, Mitra juga perlu menguassi teknologi karena teknologi syarat mutlak bagi penguasaan industri dan perdagangan. Selama Mitra masih menjalankan bisnisnya dengan menggunakan peralatan yang sederhana dan tradisional, maka Mitra tidak akan mampu bersaing menghadapi pasaran dunia. Dalam hal ini, yang utama bagi, memberikan pembelajaran e marketing, seperti pembuatan Website, Penguasaan SEO (Search Engine Optimization). (6) Pendampingan dalam pengurusan Izin usaha, dan pendaftaran Merk, sehingga Mitra mampu bersaing dan membuka pasar yang seluas-luasnya. (7) Mendantangkan pelaku usaha (UMKM) yang sukses dan Praktisi Internet Marketing, dalam rangka meningkatkan motivasi pemilik usaha dan karyawan agar mampu terus berusaha dan bersaing dengan produk lainnya.
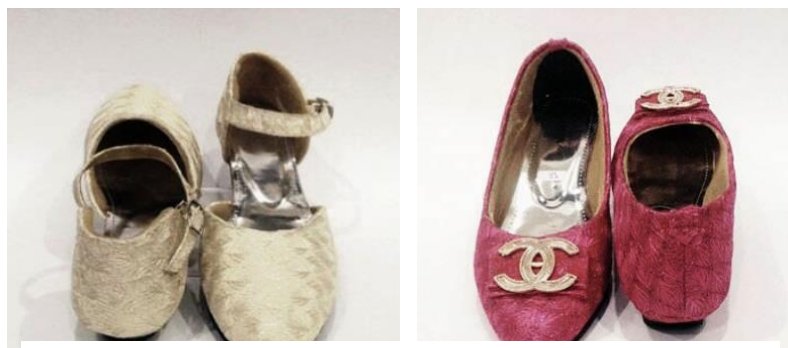

Gambar 1: Hasil Produksi Sepatu Whindy Femme Shoes (Pengrajin Sepatu Wanita)
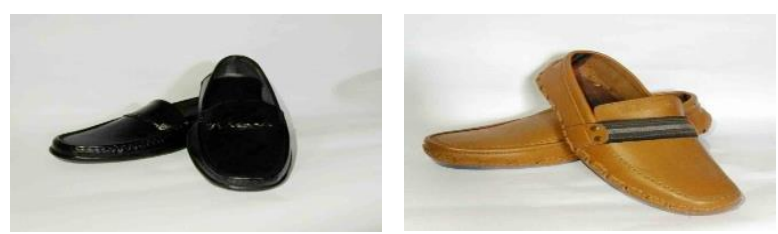

Gambar 2: Hasil Produksi Sepatu Jondy Shoes (Pengrajin Sepatu Pria)
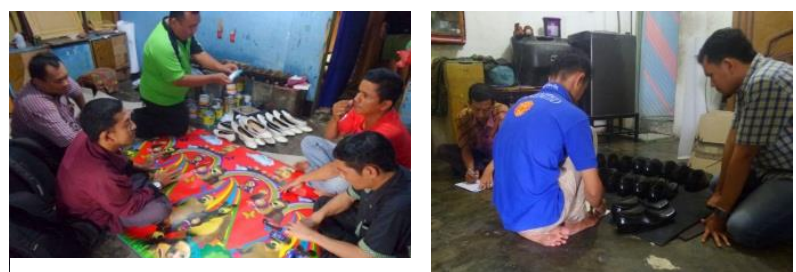

Gambar 3: Identifikasi Lapangan Team IbM ke pelaku usaha Mikro Pengrajin Sepatu di Kecamatan Medan Denai

\section{HASIL DAN PEMBAHASAN}

Setelah melaksanakan tahapan kegiatan dan metode pendekatan yang dilakukan oleh Tim pengabdian masyarakat melaksanakan Workshop Manajemen Usaha dan e-marketing yang diikuti oleh Mitra Windy Shoes (pengrajin Sepatu Perempuan dan Jondy Shoes (pengrajin sepatu Pria), Tim Pengabdian Masyarkaat di bantu oleh beberapa mahasiswa Fakultas Ekonomi dan Bisnis Universitas Muhamamdiyah Sumatera Utara, yang dilaksanakan pada tanggal 13 Maret 2017 di Jalan Bromo Kecamatan Medan Denai Kota Medan.

Dalam melakasanakan kegiatan pengabdian masyarakat ini mitra memberikan kontribusinya terhadap pelaksanaan program kegiatan pengabdian masyarakat adalah (1) Mitra selalu menumbuhkan kemampuan untuk berpartisipasi, sehingga proses pengabdian masyarakat dapat meringankan beban dan akhirnya kegiatan pengabdian masyarakat dapat dirasakan oleh Mitra, (2) Mitra mengkuti akan seluruh rangkaian kegiatan dalam pelaksanaan kegiatan pengabdian sehingga apa yang dilakukan tim pengabdian masyarakat, Mitra mau melakukan sesuai dengan kebutuhan usaha mitra, (3) Setiap apa yang diusulkan Tim Pengabdian Masyarakat untuk pembinaan usaha, seperti perbaikan administrasi, perbaikan kemasan produk, Mitra mau melakukannya secara berkelanjutan. Melakukan promosi dengan menggunakan media internet, diharapkan dapat meningkatkan penjualan.

\section{Manajemen Usaha}

Selama ini mitra tidak melakukan pencatatan terhadap keuangan usaha, sehingga menyulitkan mitra untuk melakukan perhitungan berapa keuntungan yang mereka peroleh. Dalam kegiatan pengabdian masyarakat ini mitra diajarkan langsung bagaimana menghitung biaya produksi dan manajemen usaha sehingga mitra mampu melakukan manajemen secara sederhana dan mulai merubah majamen usaha secara perlahan-lahan. Secara sederhana Mitra diajarkan dalam Penetapan harga satu unit produk sama dengan biaya total unit ditambah dengan margin laba yang 
diinginkan per unit produknya. Sehingga secara matematika dirumuskan sebagai berikut:

\section{Harga jual = biaya total + Profit Margin}

Misalkan: Seorang pengrajin sepatu dengan ukuran 39 ingin menentukan harga jual sepatu per pasang sebagai berikut:

Kulit Sepatu 2 lembar kulit menghasilkan $=7$ unit pasang sepatu

Harga Per 2 lembar kulit= Rp. 70.000,-

Biaya total Kulit=2 Lembar $x$ Rp. 70.000,-= Rp. 140.000,-

Biaya jahit per pasang sepatu= Rp. 4.000,-

Biaya total Jahit sepatu=Rp. 4.000,- $\mathrm{x} 7=\mathbf{R p}$. 28.000,-

Biaya Sol per unit pasang sepatu= Rp. 5.000,-

Biaya total soal perunit pasang sepatu $=$ Rp. 5.000,- $\mathrm{x}$ 7 = Rp. 35.000,-

Biaya pengemasan per pasang sepatu $=$ Rp. 200

Biaya total pengemasan perpasang sepatu $=$ Rp. $200 \mathrm{x}$ 7 = 1.400,-

Biaya tenaga kerja per pasang sepatu $=$ Rp. 1.000,-

Biaya total tenaga perpasang sepatu $=$ Rp. $1.000,-\mathrm{x} 7$ $=$ Rp. 7.000,-

Biaya total produksi sepatu perpasang $=$ Rp. 140.000

+ Rp. 28.000,- + Rp. 35.000,- + Rp. 1.400,- + Rp. 7.000,- + Rp. 1.400,- + Rp. 7.000,- = Rp. 211.400,-

Laba yang diinginkan (profit margin) $=30 \%$ dari biaya total produksi sepatu:

$=30 \%$ x Rp. $211.400,-=\mathbf{6 3 . 4 2 0}$,-

Harga jual total $(7$ pasang sepatu $)=$ Rp. $211.400,-+$ Rp. 63.420,- = Rp. 274.820

Harga jual per unit pasang sepatu=Rp. 274.820,- : $7=$ Rp. 39.260,- atau Rp. 40.000

Jadi dari contoh perhitungan di atas maka pengrajin sepatu dapat menjual sepatu sepasang seharga Rp. 40.000,- kepada konsumen langsung maupun kepada agen.

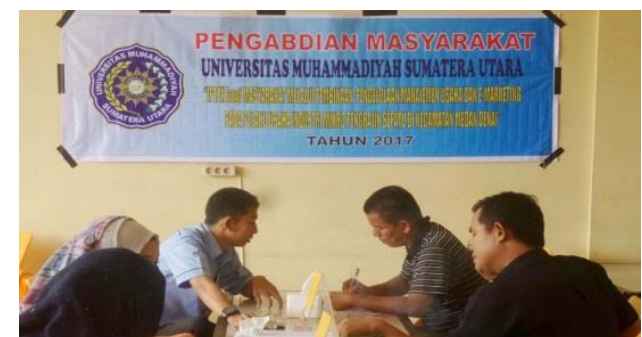

Gambar 4: Mitra Praktek Manajemen Usaha dalam menghitung Biaya Produksi

\section{E-marketing}

Karena produk pengrajin sepatu Jondy dan Whindy ini tidak kalah dengan produk luar negeri, dan peran dari pengabdian masyarakat dapat memberikan pembinaan, masukan dan pendampingan agar para pelaku usaha dapat meningkatkan perekonomian keluarga Mitra. Para Mitra dibekali dengan memberikan wawasan kepada para Mitra pengrajin sepatu tersebut, agar dapat mengerti memanfaatkan peran dunia digital di saat ini. Artinya, dengan dunia digital mereka dapat melihat peluang baru di dunia online, serta dapat memanfaatkan fasilitas tersebut, seperti blog, sosial media, serta mendaftarkan iklan usaha mereka ke toko-toko online dan sebagainya. Mitra diajarkan dengan cara yang sangat praktis dan mudah dimengerti sebagai tahap awal dari pengabdian masyarakat ini, agar Mitra lebih mudah dalam mengakses internet dalam memasarkan sepatu yang Mitra produksi. Sebelum berjualan di online, Mitra juga di diajarkan riset pasar, yakni mereka harus tahu minimal kompetitor mereka, kemudian ruang bisnis yang menjadi tren di tahun ini, lalu sebuah strategi agar pengembangan usaha mereka meningkat secara drastis. Selain itu juga mereka diajarkan mempromosikan produk Sepatu di internet tanpa seperti promosi, namun seperti informasi biasa agar pertemanan atau "follower" mereka tidak jenuh.

Langkah-langkah Pembuatan Blog UsahaMitra sebagai berikut :

1. Pembuatan Email disarankan menggunakan www.gmail.com, (2) Setelah email dibuat maka langkah selanjutnya dalam pembuatan e-marketing berbasis blog sebagai berikut : (1) Buka situs www.blogger.com. Muncul situs www/blogger.com, seperti:

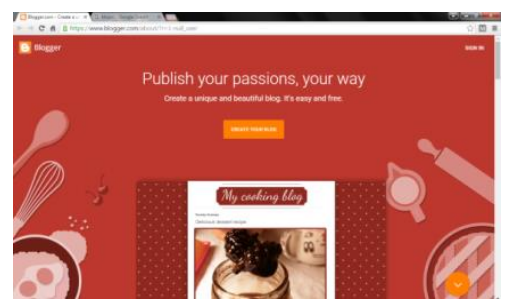

2. Setelah muncul gambar seperti di atas maka pilih SIGN IN di Pojok Kanan Atas, setelah itu muncul kotak dialaog seperti :

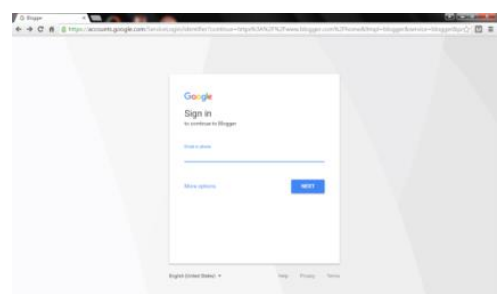

3. Masukkan email yang telah dibuat kemudian piih NEXT, masukkan password maka akan mucul menu-menu Blog yang siap untuk di kelola :

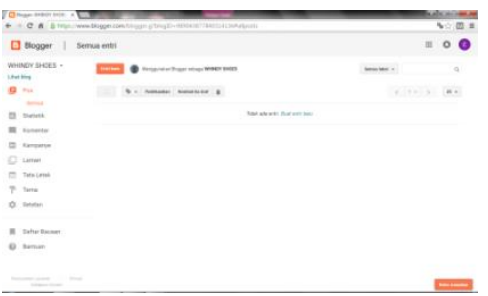

4. Kemudian Pilih Menu Paling atas dibawah gambar BLOGGER, Klik Tanda Panah Kebawah maka 
akan muncul pilihan. Pilih BLOG BARU. Maka akan muncul kota dialog seperti dibawah ini :

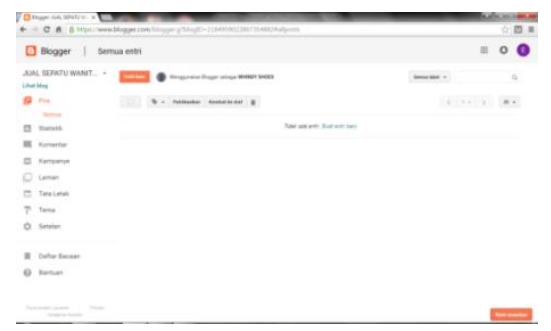

5. Pada Kolom JUDUL: Ketikan Judul yang akan dibuat, misalnyak nama Toko yang akan dibuat untuk memasarkan Sepatu "JUAL SEPATU WANITA DI MEDAN". Disarankan membuat nama terlebih dahulu melakukan Search Engine Optimation (SEO).

6. Pada Kolom Alamat. Tulis alamat website atau url yang akan kita sebarkan ke konsumen, agar konsumen bisa membuka link alamat tersebut. Buatlah alamar URL yang mudah diingat dan mudah dicari oleh konsumen. Misalkan "sepatuwanitamurahmedan.blogspot.com.

7. Setelah itu pilihlah tema yang ada dibawah Alamat seperti gambar di atas, sesuaikan tema dengan selera pengguna Blog. Disarankan memilih tema jangan terlau banyak variasi, karena akan mempengaruhi kinerja Blog, semakin banyak variasi maka blog akan semakin berat.

8. Setelah Tema dipilih Maka Pilih menu BUAT BLOG yang tercantum di bawah gambar Tema. Maka akan muncul Menu Blog Baru yang sudah Kita Buat.

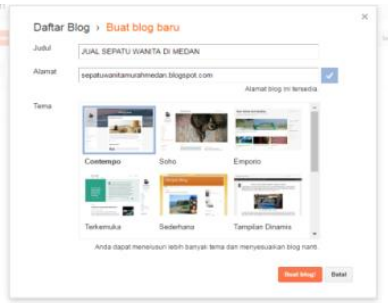

9. Pilih Menu ENTRI BARU, maka muncul kota dialog seperti :

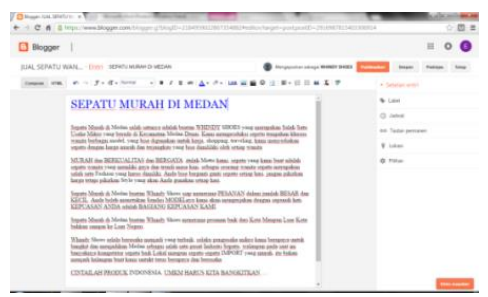

10. Pada Kotak ENTRI : JUDUL POS Isikan judul yang ingin kita buat untuk dipulikasikan

Misalkan "SEPATU WANITA MURAH DI MEDAN" Setelah diketik maka pindahkan Kursor ke halaman (Page). Isikan Tentang Profil usaha maupun deskripsi tentang produk-produk yang akan dijual.

11. Pada menu-menu dibawah ini terdapat banyak pilihan yang bisa digunakan :

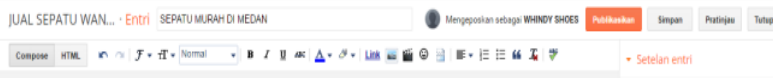

ICON "F" bisa kita gunakan untuk mengganti jenis hurup yang kita inginkan, ICON "T" bisa kita gunakan untuk memilih ukurang FONT apakah Small (kecil), Normal atau Large (besar), ICON B (untuk mengatur hurup tebal), Icon I (untuk mengatur hurup miring), Icon $\underline{\mathrm{U}}$ (untuk mengatur hurup yang mau kita beri garis bawah). Icon A (untuk memberikan warna pada hurup), Icon seperti Pisau untuk memberikan warna pada kotak, Icon LINK untuk memasukkan link url/website dan Icon Image (untuk memasukkan gambar).

12. Untuk memasukkan gambar dalam Web kita agar tampilan semakin menarik maka kita Pilih INSERT IMAGE yang ada pada Kota Dialog sepert gambar diatas, setelah INSERT IMAGE di Klik maka muncul Kota Dialog seperti :

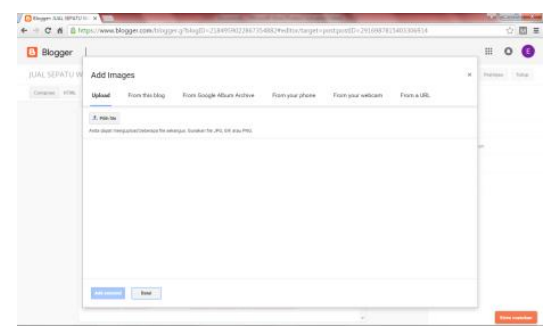

13. Pilih "FILE". Disni diminta untuk memilih file gambar yang ingin kita tampilkan dalam Blog.

14. Setelah gambar di pilih maka akan muncul gambar di kota tersebut. Maka arahakan Kursor untuk ke gambar tersebut dan tekan KLIK. Lalu pilih Add SELECTED. (Sebaiknya gambar berextention JPEG dan beresolusi rendah, karena akan memnpengaruhi kinerja Blog). Maka tampilan blog akan sperti ini

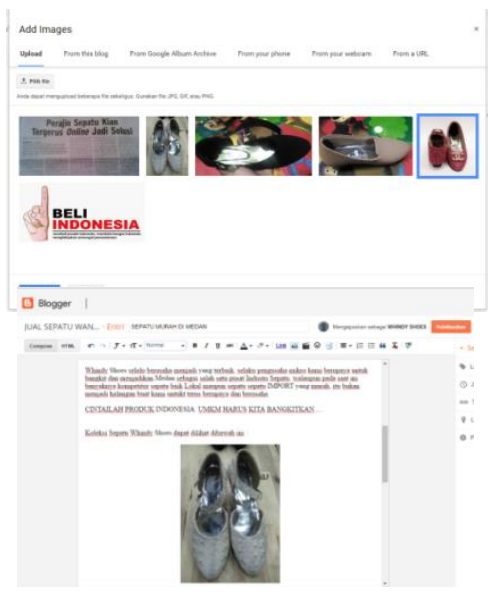


15. Setelah semua gambar dimasukkan ke dalam halaman Blog maka selanjutnya pilih Menu di Pojok Kanan Atas SIMPAN. Setelah itu Pilih di Pojok Kanan Atas PUBLIKASI, maka akan muncul kota dialog seperti :

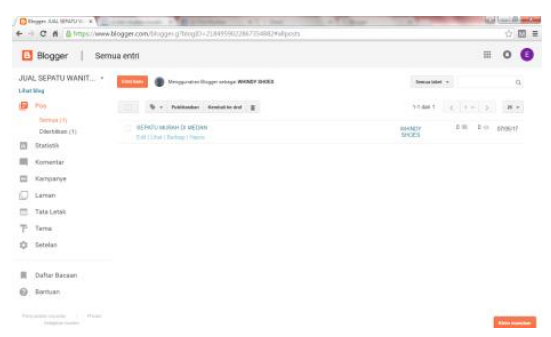

16. Setelah muncuk seperti gambar di atas maka terlihat blog yang kita Nama Blog yang telah diselesaikan. Dibawahnya ada Menu EDIT, LIHAT, BERBAGI dan HAPUS. Menu menu tersebut bisa kita gunakan untuk mengedit, melihat blog serta menghapus blog tersebut. Klik Menu LIHAT, maka akan terlihat tampilan blog kita seperti berikut:

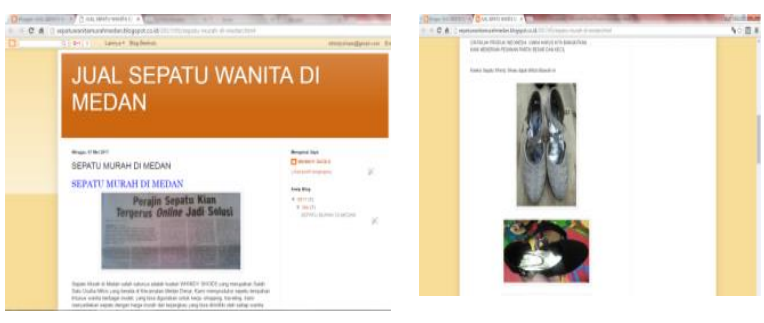

17. Maka Toko online berbasis blog sudah selesai, kemudian Copy link yang berada di kota atas blog , link tersebutlah yang nantinya akan disebarkan ke berbagai penjuru melalui media social seperti facebook, BBM. Whats App, Twitter dan lain sebagainya. Contoh link yang ada di kota dialog seperti sepatuwanitamurahmedan.blogspot.co.id. seperti terlihat pada gambar dibawah ini:

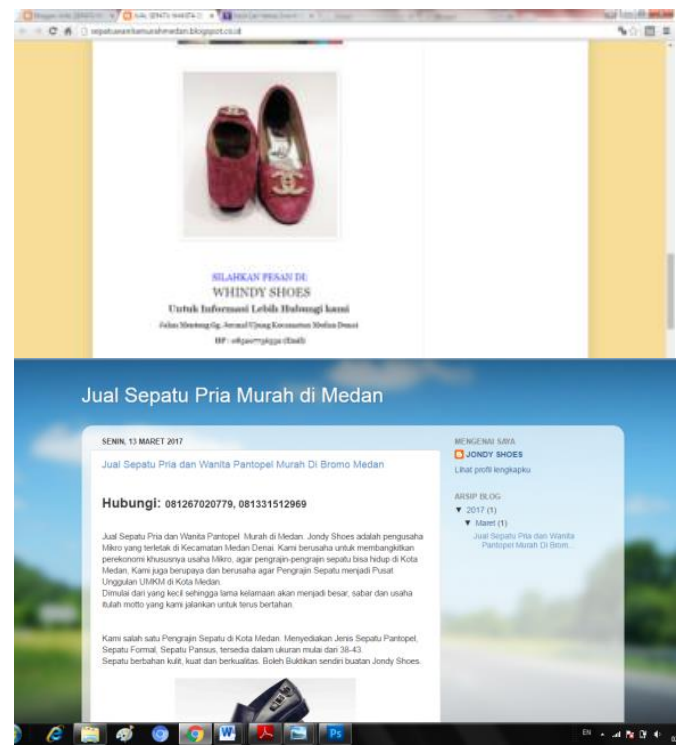

Maka website blog pengrajin sepatu tersebut sudah bisa dipublikasikan melalui media social seperti Facebook, istagram, BBM WhatsApp cukup dengan mengcopy link nya saja seperti link berikut: http://sepatuwanitamurahmedan.blogspot.co.id dan http://jualsepatupriamedan.blogspot.co.id .

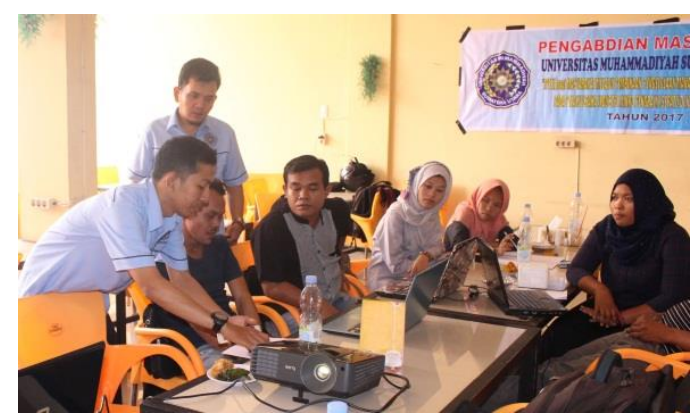

Gambar 4: Mitra Praktek membuat website Blog usaha

Secara umum pelaksanaan pengabdian masyarakat melalui pembinaan dan pengelolaan manajemen usaha dan e-marketing sudah dilaksakanan sesuai program dan mencapai keberhasilan yang dapat dilihat dari beberapa indikator yang telah ditetapkan antara lain: (1) adanya dukungan dari Pemerintah Kota Medan dan Kecamatan Medan Denai untuk memberikan izin pelaksanaan kegiatan ini. (2) Keterlibatan mitra dalam mengikuti seluruh rangkaian kegiatan pengabdian masyarakat ini, (3) Meningkatnya pemahaman Mitra dalam hal manajemen usaha dan e-marketing sebagai salah satu solusi mengatasi permasalahan Mitra.

\section{KESIMPULAN}

Kegiatan pengabdian kepada masyarakat telah dilaksanakan sesuai program yang direncanakan. Program ini dinyatakan berhasil sesuai target luaran yang telah ditetapkan, antara lain adanya keterlibatan Dua Mitra dalam pelaksanaan kegiatan ini, dan Mitra telah memiliki website untuk melakukan promosi dan penjualan melalui online, disamping itu juga meningkat pemahaman Mitra dalam melakukan manajemen usaha guna salah satunya guna menentukan harga produksi dan harga jual sepatu yang Mitra produksi. Bagi pengusaha mikro pengrajin sepatu kegiatan pengabdian masyarakat ini sangat sangat bermanfaat dalam pengembangan usaha mereka, apalagi usaha mereka memerlukan promosi yang baik agar bisa meningkatkan penjualan, disamping itu juga penerapan majamen usaha yang telah diajarkan tim pengabdian masyarakat sangat bermanfaat bagi mitra, dari sebelumnya tidak mengetahui cara manajemen usaha dengan adanya kegiatan ini mitra memiliki sudah memiliki pengetahuan, Pelaksanaan pengabdian masyarakat ini mampu memberikan peningkatan ketrampilan dan menambah wawasan bagi para pelaku usaha mikro pengrajin sepatu, Mitra telah miliki izin usaha dari pemerintah setempat dan akan didaftarkan di Dinas 
Koperasi agar mitra mempunyai jaringan untuk memasarkan produk sepatu yang mitra produksi, adanya peningkatan motivasi dan kesadaran agar tetap mempertahankan usaha dikarenakan Usaha mikro salah satu penopang perekonomian di Negara ini. Bagi Peneliti maupun pengabdian masyarakat selanjutnya banyak permasalahan-permasalahan yang dialami oleh pengusaha mikro diantaranya lemahnya pengetahuan tentang kualitas produk, sistem promosi, selling skill, packaging, terutama dalam menerapkan Bauran Pemasaran, disamping itu juga SDM menjadi hal yang mendasar, para pelaku usaha mikro ini harus terus mendapatkan motivasi dan kompetensi dalam usaha, agar usaha mereka tetap berjalan dan tidak stagnan. Pihak Perguruan Tinggi sangat dibutuhkan untuk membantu para pelaku usaha mikro dalam transfer keilmuwan maupun kegiatan-kegiatan lainnya yang dapat meningkatkan usaha mikro di Indonesia.

\section{UCAPAN TERIMA KASIH}

Tim Pengabdian Masyarakat mengucapkan terima kasih kepada Rektor Universitas Muhammadiyah Sumatera Utara, Jajaran Dekanat Fakultas Ekonomi dan Bisnis Universitas Muhammadiyah Sumatera Utara, Lembaga Penelitian dan Pengabdian Kepada Masyarakat Universitas Muhammadiyah Sumatera Utara, untuk pendanaan kegiatan ini melalui Hibah APB UMSU Tahun Anggaran 2016/2017. Terima kasih juga Tim pengabdian masyarakat ucapkan kepada Pemerintah Kota Medan dan Kecamatan Medan Denai serta para Mitra yang terlibat dalam kegiatan pengabdian masyarakat dan pihak-pihak yang turut serta mendukung kegiatan pengabdian masyarakat ini.

\section{DAFTAR PUSTAKA}

Alhempi R. R. dan Wismar, H., (2013). Pengaruh Pelatihan Dan Pembinaan Terhadap Pengembangan Usaha Kecil Pada Program Kemitraan Bina Lingkungan. STIE dan STIH Persada Bunda Pekanbaru. Media Riset Bisnis \& Manajemen, Vol. 13, No. 1, April 2013. Hal. 20-38.

Ay Ling. (2013). Pengelolaan Dan Pengembangan Usaha Pada Usaha Mikro Kecil Menengah (Studi Deskriptif Pada Rumah Makan Palem Asri Surabaya). AGORA Vol. 1, No. 1. Tahun 2013. Hal 1-7.

Badan Pusat Statistik. (2016). Statistik Daerah Kecamatan Medan Denai. Medan: BPS Kota Medan.

Djamaludin, Aviasti, Rukmana Asep Nana, Rukmana Otong. (2016). Peningkatan Kemampuan Usaha Kecil Menengah Di Wilayah Bandung Raya Dalam Pemanfaaatan Internet Sebagai Sarana Pemasaran Dan Perluasan Jangkauan
Pasar. Jurnal Ethos (Jurnal Penelitian dan Pengabdian Masyarakat). Volume 4 Nomor 1. Januari 2016. ISSN 1693-699X (Print), ISSN 2502-065X (online). Hal 125-130.

Dwivedi, A. (2004). Metodelogi Pelatihan Partisipatif. Yogyakarta: Pustaka Yogya Mandiri.

Nuryanti. (2013). Peran E-Commerce Untuk Meningkatkan Daya Saing Usaha Kecil Dan Menengah UKM). Jurnal Ekonomi. Volume 21, Nomor 4 Desember 2013. Hal 1-15.

Mujiyana, Sularto Lana, Mukhyi M. Abdul. (2012). Pengaruh Penerapan Periklanan Di Internet Dan Pemasaran Melalui E-Mail Produk UMKM Di Wilayah Depok. J@TI Undip, Vol VII, No 3, September 2012.

Suherman, E. (2012). Kiat Sukses membangun SDM Indonesia. Bandung: Alfabeta 